\title{
ВІД РЕДКОЛЕГІї
}

Редакційна колегія електронного наукового фахового видання міжквідомчого тематичного збірника "Історія науки та біографістика» прийняла рішення щодо оприлюднення мемуарів кандидата технічних наук, старшого наукового співробітника Національного наукового центру "Інститут механізації та електрифікації сільського господарства» НААН Москаленка Степана Пантелесвича, враховуючи актуальність проблеми механізації тваринництва на сучасному етапі розвитку галузі, а такожс особистий внесок талановитого вченого у розроблення основ механізованого процесу машинного доӥння корів, щңо дозволило сформулювати вихідні положення $і$ визначити периметри функціонування біотехнічної ланки виведення молока з вимені тварини, застосувати ӥх при розробці машин $і$ устаткування для доӥння корів.

Як відомо, інтенсивний розвиток галузі і успішне виконання завдань щцодо збільшення виробництва продукції тваринництва можеливі за умови прискорення науково-технічного прогресу. Це потребує постійного $i$ масштабного здійснення технічного переоснащення виробництва, завершення комплексної механізації $i$ автоматизації на основі використання науково обтрунтованої системи машин. Розробка таких систем передбачає подальший розвиток виробництва високоякісної продукціï, підвищення продуктивності $i$ покращання умов праці обслуговуючого персоналу, зайнятого у виробництві, економії матеріальних та енергетичних ресурсів, а також вирімення задач щодо охорони навколишнього середовища. Таких результатів можнн досягти на основі: впровадження прогресивних технологій і технологічних процесів; розробки, виготовлення і поставки комплектів машин та обладнання для всього виробничого циклу, включаючи $i$ засоби механізації допоміжних транспортно-перевантажувальних та інших операцій, а також контролю i управління технологічними процесами; переходу від автоматизації окремих операцій $і$ процесів до комплексної - на рівні технологічних ліній, цехів $i$ всього виробництва; підвищення технічного рівня, надійності $i$ довговічності випущених технічних засобів, їх технологічної універсалізації та уніфікації; здійснення реконструкції $i$ технічного переоснащення існуючих підприсмств.

Найбільи трудомістким процесом, на який припадає 60-80\% затрат усієї праці, є доӥння. Від його організації, системи й конструкції доӥльного обладнання залежить не лище продуктивність і якість молока, а й здоров'я тварин. Машинні технології в тваринництві пройшли довгий илях становлення і розвитку, трунтуючись на досягненнях науково-технічного прогресу та знаннях закономірностей фізіологї $i$ етіології сільськогосподарських тварин, визначаючись переважаючими системами утримання. На сучасному етапі, коли здійснюсться активний пошук шляхів зростання конкурентоспроможності галузі вітчизняного 
тваринництва, вивчення та творче використання історичного досвіду окремих учених представляється практично значущим.

$$
\text { * * * }
$$

Москаленко Степан Пантелесвич народився 1 вересня 1935 р. в с. Бужанка Лисянського району Київської області (з 1954 р. Черкаської). В 1944-1954 рр. навчався в Бужанській середній школі. У 1954-1957 рр. служив у лавах Радянській Армії в мотострілецькому полку в м. Каунасі Литовськой РСР; мав звання старшого сержанта.

31957 р. навчався на факультеті механізації сільського господарства Украӥнської сільськогосподарської академії. В 1962 р. одержсав диплом інженера-механіка сільськогосподарського виробництва $i$ за направленням став працювати в Украӥнському науково-дослідному інститутів механізації та електрифікації сільського господарства (УНДІМЕСГ).

В 1962-1974 рр. - молодший науковий співробітник відділу механізації процесів великої рогатої худоби. В 1967-1971 рр. - аспірант-заочник у цьому же відділі; виконував наукову роботу - дисертацію під керівництвом к. т. н. А.А. Яворського.

У листопаді 1974 р. захистив дисертацію "Дослідження режимів транспонування молока по трубах на молочно-товарних фермах $i$ комплексах» на здобуття наукового ступеня кандидата технічних наук за спеціальністю 05.20.01 «Механізація сільськогосподарського виробництва».

3 листопада 1975 р. - старший науковий співробітник лабораторії машинного доӥння і первинної обробки молока УНДІМЕСГ. У квітні 1980 р. С.П. Москаленку присвосно звання старшого наукового співробітника зі спеціальності «Механізація сільськогосподарського виробництва».

31999 р. працював провідним науковим співробітником, завідуючим аспірантурою, вченим секретарем спеціалізованої вченої ради із захисту докторських та кандидатських дисертацій.

Автор 160 наукових праць, в 11 рекомендацій, 13 авторських свідоцтв та патентів на винаходи.

31995 р. - пенсіонер; в грудні 2013 р. звільнився з роботи в ННЦ "Інститут механізації та електрифікації сільського господарства" НААН. 


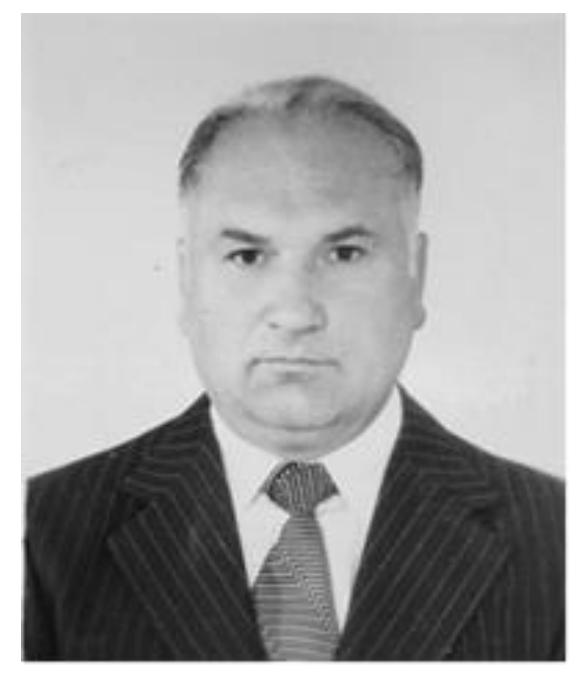

\section{МОСКАЛЕНКО \\ Степан Пантелесвич}

кандидат технічних наук, старший

науковий співробітник,

Національний науковий центр

«Інститут механізації та

електрифікації сільського

господарства» НААН

(м. Київ, Україна)

\section{ПРО ТЕХНОЛОГІЧНИЙ ЛАНЦЮГ «ЛЮДИНА-МАШИНА-ТВАРИНА» (СПОГАДИ)}

У спогадах висвітлені сторінки з мого життя, які відносяться до мого захоплення тваринами (коровами) та вивчення технологічного ланцюга «людина-машина-тварина», зокрема, використання тварин (корів, волів) $у$ технологічних процесах сільськогосподарського виробництва як тягла. Розглядається механізований процес машинного доїння корів дойльними установками різних типів $i$ апаратами на молочно-товарних фермах. Приділяється велика увага виконавцям процесу доӥння корів, майстрам машинного доїння (операторам). На сучасному етапі рекомендується використовувати доїльні установки параметричного ряду для молочних ферм різних типорозмірів.

Виконаний комплекс досліджень дозволив сформулювати вихідні положення $i$ визначити периметри функціонування біотехнічної ланки виведення молока з вимені тварини, щуо дає можливість застосувати їх при розробиі машин і устаткування для доӥння корів.

Ключові слова: людина, машина, тварина, доӥльна установка, молоко.

\section{ABOUT THE TECHNOLOGICAL CHAIN «MAN-MACHINE-ANIMAL» (THE MEMOIRS)}

The memoirs cover the pages of my life that relate to my passion for animals (cows) and the study of the human-machine-animal animal chain, in particular the use of animals (cows, oxen) in the technological processes of agricultural production as a tax. The mechanized process of machine milking of cows by milking installations of various types and devices on dairy farms is considered. A lot of attention is paid to 
the executors of the milking process of cows, the masters of machine milking (operators). At the present stage it is recommended to use milking installations of the parametric series for dairy farms of different sizes.

The completed complex of studies allowed us to formulate the initial assumptions and determine the perimeters of the functioning of the biotechnical link for removing milk from the udder of the animal, which makes it possible to apply them in the development of machines and equipment for milking cows.

Key words: man, machine, animal, milking plant, milk.

\section{О ТЕХНОЛОГИЧЕСКОЙ ЦЕПИ «ЧЕЛОВЕК-МАШИНА-ЖИВОТНОЕ» (ВОСПОМИНАНИЯ)}

У воспоминаниях освещены страницы из моей жизни, которые относятся $\kappa$ моему увлечению животными (коровами) и изучению технологической иепи «человек-машина-животное», в частности, применение животных (коров, волов) в технологических процессах сельскохозяйственного производства как тягла. Рассматривается механизированный процесс машинного доения коров доильными установками разных типов и аппаратами на молочно-товарных фермах. Уделяется большое внимание исполнителям процесса доения коров, мастерам машинного доения (операторам). На современном этапе рекомендуется применять доильные установки параметрического ряда для молочных ферм разных типоразмеров.

Выполненый комплекс исследований позволил сформулировать исходные положения и определить периметры функиионирования биотехнического звена выведения молока из вымени животного, что дает возможность применить их при разработке машин и оборудования для доения коров.

Ключевые слова: человек, машина, животное, доильная установка, молоко.

\section{МОЛОКО}

Как молоко парное, цедят ветви

Березовой цедилкою туман.

И, теплый, он, дымясь, течет к повети -

Хоть подставляй скорей пузатый жбан.

Вот струйки из тугих сосков буренки

Под пальцами проклюнулись легко.

Сквозь годы слышу я твой запах тонкий,

Хлеб детских лет - парное молоко ...

Трава жилплощадь отдает бетону, И глушат голос птиц басы гудка,

Но утром весело гремят бидоны -

Я славлю

Беспрерывность молока! 
Пропахшая дорогами и ветром,

Машина, как буренка, у лотка

Своим сигналом мыкнет на рассвете,

И заиграют струи молока

Ты в свой рожок

мычи,

труби,

корова,

С отавных берегов молочных рек,

Одну твою рогатую корону

Не сбросит с трона мой бунтарский век.

Мы пьем рассветов белых сыродой,

Когда, как струи молока о донце,

Журчит лучами над лугами солнце -

И кровь играет силой молодой!

(Пер. с білорус. Броніслав СПРИНЧАН)

\section{Корова Машка}

Корова - священна тварина в Індії. Для мене вона священна і в нас в Україні. Коли почалася Велика Вітчизняна війна в 1941 р., мій батько Пантелеймон Мусійович пішов на фронт. Ми, четверо дітлахів Микола, Маруся, я Степан і Петя, залишились в селі на Черкащині (тоді - Київщині). У вересні місяці народився ще один братик Вася.

У нашому господарстві були кури, гуси, поросята i, звичайно, корова Машка. Для всієї великої сім'ї вона була годувальницею. При триразовому доїнні мама надоювала три дійниці молока. Була і сметана, і сир, і навіть масло.

Йшла зима 1944 р. Не буду описувати перипетії Корсунь-Шевченківської битви. Все це відомо з історії. Село Бужанка на Лисянщині переходило з рук у руки тричі. Наша сім’я під час стрілянини пішла в погріб наших сусідів - сім’ї 3 шести осіб. Коли трохи затихло, перейшли до хати сусідів. Їхня хата стояла трохи вище від дороги. В хаті було тепло, бо їхня бабуся натопила лежанку і грубку. Дві сім'ї грілись на лежанці біля грубки в маленькій кімнаті. Дорога обстрілювалась. Один снаряд попав вище вікна і розірвався. Сусідню дівчинку Ніну вбило на смерть. Всі інші члени сімейств були поранені. Мене навіть не зачепило. Наші літаки обстрілювали німецькі вантажі - бочки з бензином. Одна 
3 бомб упала і розірвалась на городі в сусіда за хлівом, де знаходилась наша Машка. Ї̈̈ було поранено осколком в шию, сочилася кров. Мама нагріла води $\mathrm{i}$ замочувала наші і коров'ячі рани.

Після звільнення села від німецько-фашистських загарбників треба було обробляти землю, сіяти i збирати врожай. $\mathrm{He}$ було тягла для сільськогосподарських знарядь. Основними робітниками в колгоспі були жінки і діти. Весною мені довелось не тільки пасти, а й закладати в ярмо нашу Машку і сусідську Білку. Я за допомогою налигача водив в борозні цих корівок при обробітку землі. Влітку пас Машку там у полі, де мати з іншими жінками косила жито. Корова була нашою годувальницею і в голодні 1946-1947 pp., незважаючи на те, що держава примусила здавати молоко на приймальний пункт - 320 кг на рік з корови.

Батько повернувся 3 війни і почав працювати на відгодівельному пункті їздовим. Як і до війни, раненько йшов до воловні, запрягав великих сірих волів у ярмо i виконував різні сільськогосподарські роботи. Найбільш мені запам'ятались роботи, коли батько виконував транспортні роботи: возив сіно, снопи, солому, цукрові буряки, жом. Особливо запам'яталось, коли він возив 3 поля цукрові буряки на Бужанстський цукровий завод. На возі з закладками він перевозив біля 1-1,5 т цукрових буряків. Тоді коли автомобіль ГАЗ-ММ перевозив до 1,5 т.

Корова Машка взимку 1947 р. привела двох теляток: бичка і теличку. Весною ми виганяли їх на пасовище. Ми, пастухи, коли загулювались, то ці телятка 3 двох сторін корови висмоктували молоко не тільки в Машки, а й в сусідньої Білки. Просто біда... Машка восени почала хворіти. Доїлась на три, а згодом на дві дійки. Батько здав її на відгодівельний пункт. Після Машки нам на корів не щастило. Корів, які були у нас після Машки, по черзі пасли мої брати Петя і Вася. 


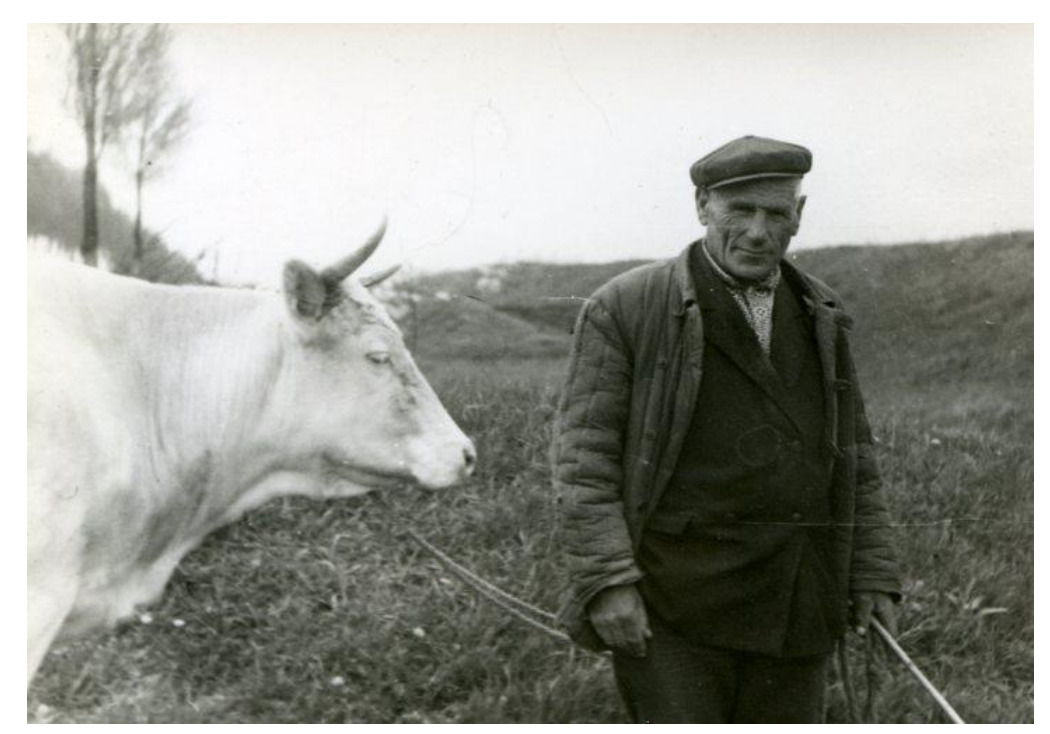

Корова Машка 5 з пастухом, моїм батьком,

Пантелеймоном Мусійовичем Москаленком. 1970 p.

\section{Погонич волів}

Кожного року з 50-х рр. на канікулах я працював в колгоспі погоничем волів. Доглядачем волів, з якими я працював, був мій хрещений батько Щука Ярофей. Волів утримували на прив'язі і розміщували в приміщенні відповідно бригадному номеру попарно: підручний і борозній відповідно. Над годівницею висіли ярма для кожної пари волів. Хрещений мене наставляв, як поводяться ці тварини. Деякі бились рогами, а інші - задніми кінцівками. Найбільш мені подобалось працювати з рижими з білими лисинами волами. Це були «розумні» і швидкі тварини. В самохідну жатку «Ідеал» чи «Комунарка» ми впрягали їх по дві пари, періодично міняючи їх на відпочинок, годування, напування. Зі своїм сусідом Сашком ми орали і навіть сіяли гречку. Волами я возив на скиртуванні сіно, снопи до стіжка чи молотарки, зерно від молотарки до колгоспної комори, возив гній від тваринницької ферми до поля.

Наприкінці літа ми виконували глибоку оранку на зяб. За світловий день 3 перервою на відпочинок, годівлю і напування волів, ми виорювали 1-1,25 га ріллі. Оранка, чи обробіток грунту, були моєю улюбленою справою. Коли хворів мій сусід Попко Кирило, через бригадира він доручав саме мені його робочих коней. Я любив робочу худобу, вчасно ії зупиняв на відпочинок, 
годівлю і напування. Інколи взимку під час навчання в школі, довідувався про своїх волів у хрещеного.

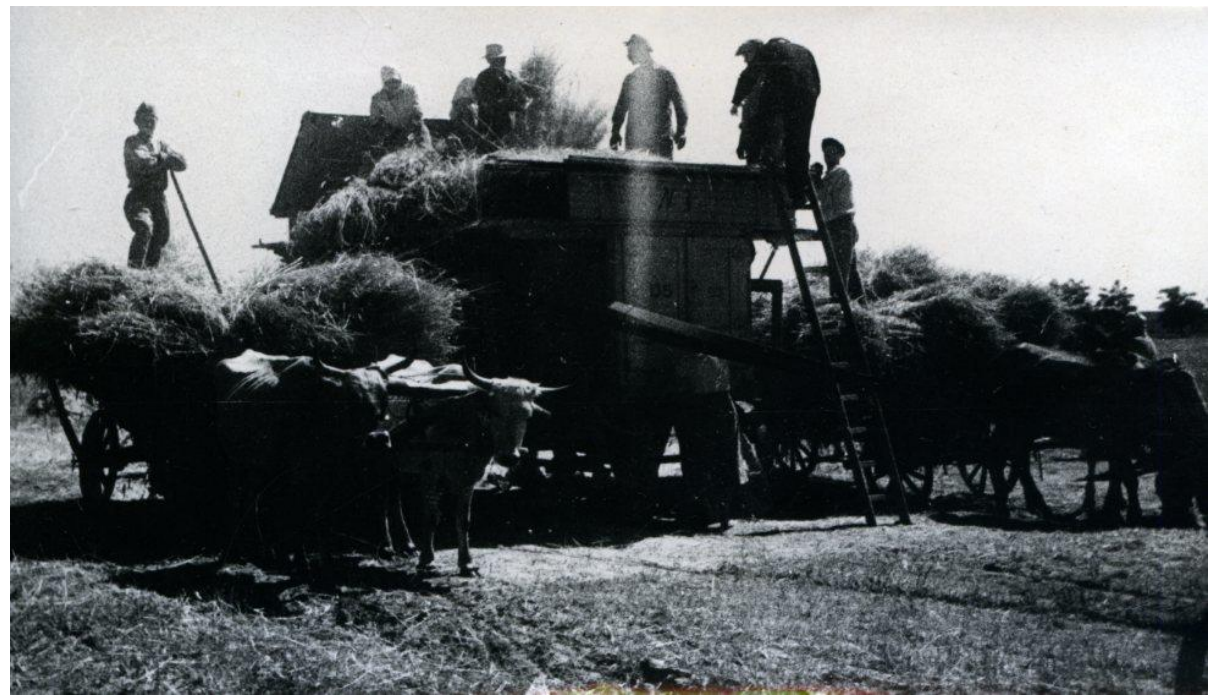

Молотьба хліба. Подаю снопи до барабана молотарки. $1950 \mathrm{p}$.

\section{Не забував про корів під час служби в армії}

На заняттях 3 політичної підготовки у вечірній партійній школі ми вивчали історію партії. На цих заняттях інколи було скучнувато. За одним столом зі мною сидів узбек Догмагомбетов з Ташкента. Він добре володів російською мовою і завжди читав «Комсомольскую правду», нехтуючи вести конспект занять.

Один раз він показав у «Комсомольской правде» маленьку замітку, мовляв, це для тебе, адже ти сільський і любиш корів і молоко. В замітці мова йшла про те, що студентка третього курсу Курганського сільгоспінституту Багрецова Інна, перебуваючи на практиці, роздоїла притаманним їй методом групу новотільних корів, що дало змогу значно підвищити їх продуктивність. Прийшовши до ленкімнати в особисту годину, я ще раз перечитав замітку i вирішив написати листа студентці. Так зав'язалась переписка. Інна детально описала свій метод доїння на сторінках учнівського зошита. Розпочата переписка тривала навіть тоді, коли я був першокурсником УСГА. Ми обмінялись фотокартками. Хто тоді міг подумати, що на мою майбутню професіональну діяльність ця подія так вплине! 


\section{Про студентські роки}

Під час навчання в УСХА на факультеті механізації сільського господарства прослухав курс з тваринництва і одержав залік. На четвертому курсі прослухав лекції з механізації тваринництва, виконав і здав курсовий проект «Пастеризатор молока», а також іспит, де мені в білеті було питання про будову і роботу доїльного апарата, зокрема пульсатора. Здав іспит на «добре».

\section{Наукова робота}

Після закінчення УСХА був направлений на роботу до Українського науково-дослідного інституту механізації та електрифікації сільського господарства (УНДІМЕСГ). На співбесіді в заступника директора 3 наукової роботи кандидата технічних наук Кукти Григорія Максимовича мені було запропоновано посаду молодшого наукового співробітника у відділ механізації технологічних процесів на фермах великої рогатої худоби (ВРХ) зі штатним окладом 83 крб. Отже, 6 серпня 1962 р. мене зарахували до штату УНДІМЕСГ.

Підходячи до інституту, я зустрів Фененка Анатолія Івановича, який мене завів у кімнату, де працювали співробітники відділу. Відділ очолював Яворський Альфред Альфредович, 52-річний інженер-механік, який прийшов 3 посади завідувача відділу механізації процесів у тваринництві Мінсільгоспу УРСР.

Мене призначили у групу співробітників старшого наукового співробітника А.І. Фененка, який в той час займався дослідженням процесу машинного доїння корів, вивченням нових технологій і засобів для доїння корів. Тоді якраз в практику входили установки для доїння корів у молокопровід в стійлах та доїльних залах. Свої розробки інститут перевіряв на молочних фермах радгоспу «Бориспільський», куди я був командирований для вивчення технологічних процесів.

Перше моє самостійне відрядження в один з колгоспів на Сумщині. Їхати треба було до з. с. Віри, а потім автобусом. Метою стало ознайомлення 3 роботою доїльної установки типу суміщений молокопровід ММД-100 i, зокрема, лічильниками-дозаторами молока релізерного типу. Були намагання 
придбати один комплект таких дозаторів для установки, яка була у нас в інституті і ми збирались їі змонтувати в радгоспі «Бориспільський», в одному 3 корівників на відділку ім. Кірова. Так, я вперше бачив в роботі доїльну установку зі суміщеним молокопроводом ММД-100 конструкції Київського ГСКБ машин і обладнання для тваринництва. Установка була розрахована на обслуговування 100 корів в приміщеннях корівника. Укомплектована вона була тритактними доїльними апаратами ДА-3М. Молоко по молочному шлангу від молокозбірної камери колектора доїльного апарата подавалось в суміщений скляний молокопровід, а потім по ньому транспортувалось в загальний молокозбірник - цистерну. Молокопровід збирався з окремих скляних труб довжиною 2,2 м 3 внутрішнім діаметром 38 мм і монтувався над стійлом на дошці. Суміщений кран для молочного і повітряного шлангів доїльного апарата встановлювався між стійлами двох сусідніх корів. Окремі ділянки молокопроводу та суміщені крани з’єднувались в одну лінію за допомогою гумових муфт. Для обмивання вимені i промивки лінії молокопроводу установки комплектувались ємкістю з насосом типу «Кама». При розміщенні молокоприймального відділення в бічній частині корівника монтувалось чотири тупикових віток молокопроводу.

Обслуговувала кожну вітку молокопроводу одна доярка - майстер машинного доїння (ММД). Після закінчення доїння 3 торця лінії молокопроводу для збирання залишків молока пропускали роздільник «пиж» 3 гуми-губки або паралону. За годину доярка видоювала до 20 корів. Сдина перевага перед доїнням в доїльний бідон - відпала необхідність збирання молока у фляги та його транспортування в молочне відділення. Існували недоліки: інерційність в режимі доїння і транспортування молока, відсутність обліку молока від окремої групи корів та складність промивання молокопроводу.

Монтаж такої установки було здійснено в одному з корівників відділку ім. Кірова радгоспу «Бориспільський» під керівництвом А.І. Фененка Монтувала установку бригада робітників під керівництвом інженера 3 
механізації робіт в тваринництві М.I. Кавуна. Я вперше приймав безпосередньо участь під час монтажу для удосконалення процесу промивки молокопроводу ми закільцювали його.

У радгоспі «Бориспільський» на відділку «Промінь» (з 1965 р. - радгосп «Промінь») будувалась молочно-товарна ферма на 1200 корів (6 приміщень корівників на 200 голів кожний) - за проектом № 586 ПК УкрНДІГІПРОСІЛЬГОСП.

Міністерство сільського господарства та «Сільгосптехніка» вирішили на базі цієї молочної ферми перевірити комплекс машин для виробництва молока 3 прив'язним утриманням корів i, зокрема, різні типи доїльних установок «Тандем». «Ялинка» та «Карусель». У 1963 р. між двома корівниками був збудований доїльний зал 3 установкою «Карусель» - ДУК - 24 конструкції Київського ДСКБ з машин в тваринництві. Восени доїльний зал був введений в експлуатацію.

Роботу «Каруселі» перевіряли і контролювали представники Міністерства сільського господарства і «Сільгосптехніки», УкрМВС, УНДІМЕСГ і ДСКБ м. Київ. Наш відділ приймав участь у вивченні технології і операції техніки доїння корів, працездатність і продуктивність установки. Було виявлено ряд недоліків, які спонукали призупинити цей експеримент. Головне: зовсім не було підібране стадо для машинного доїння. Привчання корів до доїння на такій установці проходили зі стресовими ситуаціями, доїльна установка i апарати були недосконалими. Корови швидко втрачали свою продуктивність.

Після невдалого впровадження доїльних залів в радгоспі «Промінь», де утримувалось стадо симентальської поради, потрібно було вирішувати завдання механізації доїння корів в стійлах. Знадобився досвід використання доїльної установки ММД-100 в радгоспі «Бориспільський» на відділку ім. Кірова.

За нашими розробками розпочали монтаж доїльних установок ММД-100Б з суміщеним молокопроводом і одному з корівників. Доїльну установку було змонтовано за удосконаленою схемою: кожна ділянка (вітка) молокопроводу під час доїння була тупиковою, а під час промивання - кільцевою. Робоча вітка 
розташовувалась над годівницею 3 похилом у бік молокозбірника молочної. Над в'їзними ворітьми та посередині корівника молокопровід був піднятий на висоту, що дозволяло безперешкодному проїзду трактора 3 кормороздавачем. Підйоми молокопроводу були виконані 3 нахилом 45․ Доярка (майстер машинного доїння - ММД) під час доїння працювала 3 3-4 доїльними апаратами, обслуговуючи групу 50-ти корів. Розпочинала доїння 3 найближчої до молокоприймача вітки молокопроводу так, що молоко під час доїння i транспортування весь час рухалось по «змоченій» трубі. Таким чином, під час доїння молокопровід знаходився в «змоченому» стані, що сприяло його ефективному промиванню. Після доїння залишки молока 3 молокопроводу «витісняли» шляхом пропускання по ньому 2-3 роздільників (пижів) з гуми або поролону, через пристрій (триходовий кран), що знаходився на кінці вітки молокопроводу. Під час доїння молоко надходило до молочного відділення $\mathrm{i}$ попадало в молокоприймальну ємність 3 поплавковим механізмом, де обліковувалось i виводилось 3 під вакуумметричного тиску в молокоприймальну флягу. Через те, що в суміщений молокопровід надходило молоко, спостерігалась нестабільність в роботі пульсатора із-за коливання вакуумметричного тиску.

Керівник нашої групи старший науковий співробітник А.І. Фененко запропонував об'єднати колектор і пульсатор у один агрегат, виключивши повітряний шланг, який з'єднувався 3 пульсатором. Ми знали, що в Новій Зеландії уже застосовувався такий пульсоколектор «Ну палс». Наша група автор цих рядків та механік М.Г. Шиманський змонтували такий пульсоколектор з деталей доїльного апарата ДА-3М («Волга»).

Доярка Мисюк Катерина підключила цей пульсоколектор в роботу на першу корову, яка розташовувалась в стійлі. Це була маленька корова симентальської породи - первістка. Ми іiї назвали Манюнею. Цю корівку ми вгощали кусочками хліба і цукру, які приносили після їдальні. Влітку тварин випускали на вигульний майданчик, по периметру якого була годівниця. Підійшовши до майданчика, ми кликали Манюню, і вона 3 цієї маси корів 
підходила, пригощалась нами. В експериментальному цеху УНДІМЕСГ виготовили комплект таких пульсоколекторів на весь корівник 200 голів, які успішно експлуатувались.

Проблемним питанням було промивання молокопроводів, доїльних апаратів та ємкостей. Проведені дослідження системи на бактеріальне забруднення, показали «вузькі» місця їх накопичення: це з'єднання (муфти) молокопроводу, комбіновані молочний і вакуумметричний крани, молочні і повітряні, шланги, дійкова гума i т.д. Потрібно було шукати шляхи удосконалення техніки і технології промивки. Знаходження пульсатора на відстані 1,2-1,5 м від колектора, завдяки перепаду тиску, створювало інерційність в їх роботі, сприяло малорегульованому режиму доїння корів.

Інерційність системи вдалось усунути за рахунок об'єднання пульсатора і колектора в один агрегат - пульсоколектор, завдяки чому було усунуто повітряний шланг приводу пульсатора та заглушено повітряний отвір на молокопроводі. Молочний камінь на стінках молокопроводу вдавалось видалити за допомогою пропуску 3-4 роздільників (пижів), які змочували в $0,1 \%$ розчині сірчаної кислоти (краще оцтової). Прийшлось «продірявити» не одну одежину, особливо «китайські» штани. Більшість експериментальних досліджень ми проводили безпосередньо на фермі в корівнику чи в літніх таборах. Для доїння корів в літніх таборах ми розробили прохідні станки, які виготовляли 3 дерев'яних брусів, обладнали їх впускними та випускними хвіртками і годівницями. Молокопровід над задніми стійками станків під’єднувався до молокоприймача в молокоприймальному відділенні. Таким чином, доїння, що в приміщенні, що в прохідних станках на вигульному майданчику, були ідентичними. Це давало змогу влітку без перешкод проводити ремонт і профілактику приміщення корівника та його обладнання.

Запропонована схема доїльної установки типу «Молокопровід» постійно удосконалювалась, вивчались режими іiі роботи і роботи доїльних апаратів 3 пульсоколекторами. Наші розробки були прийняті до впровадження Рижським ДСКБ по машинам для тваринництва (до 3\%) і знайшли своє втілення в 
доїльних установках Резекненського заводу - спочатку «Даугава-200», а потім АДМ-8. Доїльний апарат 3 пульсоколектором був захищений декількома авторськими свідоцтвами СРСР.

Були апробовані монтажні схеми доїльних установок з молокопроводом для випадків, коли молокоприймальне відділення знаходиться в боковій, Гподібній та торцевій прибудові корівника. Найбільш оптимальною була схема 3 торцевим молокоприймальним відділенням. Тут робоча ділянка (вітка) молокопроводу розташовувалась в одну лінію з похилом у бік молокоприймача без зайвих поворотних колін і підйомів. Це покращувало режим доїння i транспортування молока та збереження його якості.

Технологічний процес доїння корів досліджувався цілорічно. Досліджувались: повнота видоювання, стан вимені, якість молока, роботоздатність експериментальних доїльних апаратів. Ці роботи виконували окрім згаданих співробітників: старший зоотехнік (ветлікар за спеціальною освітою) С.Т. Дячинська, старший лаборант Молокова Т.I. та Утеуш М.T.

Конструкторське бюро УНДІМЕСГ розробило документацію на пульсоколектор, яку передали згідно договору на ВО заводу ім. Артема. Перші зразки деталей пульсоколекторів виготовляли і на інших заводах м. Києва.

Комплектування і збирання пульсоколекторів виконали на Броварській «Сільгосптехніці». Такі доїльні апарати були впроваджені на доїльних установках Київської обл., зокрема на молочно-товарних фермах овочевомолочних радгоспів.

Колектив розробників був премійований: Фененко А.І., Москаленко С.П., Ліщинський С.П., Миропольський О.М. У 70-х рр. вони захистили кандидатські дисертації з тематики механізації доїння і транспортування молока. Ці розробки захищені авторськими свідоцтвами СРСР, патентами України, автори удостоєні знаків «Винахідник СРСР».

Наприкінці 60-х - початку 70-х років минулого сторіччя в Союзі РСР розпочали проводити конкурси серед тваринників, які обслуговують корів доярок (майстрів машинного доїння). Такі конкурси проводились на рівні 
господарства (ферми), району, області, республіки та Союзу. Мені та іншим співробітникам лабораторії Міністерство сільського господарства УРСР доручило розробку та підготовку залікових листів для роботи суддівської комісії з оцінки виступів на конкурсі ММД, оцінювати їх роботу, як судді змагань.

Головною метою конкурсів була широка пропаганда машинного доїння корів при різних технологіях їх утримання 3 використанням сучасних $\mathrm{i}$ перспективних доїльних апаратів та установок, підвищення професійної майстерності та практичних навичок працівників, підвищення їх теоретичних знань $з$ питань використання обладнання на фермах і комплексах, дотримання зоотехнічних та ветеринарних заходів з утримання дійних корів.

За результатами республіканського конкурсу визначали збірну команду майстрів на Всесоюзний конкурс, який проводився через кожні два роки. Для підготовки виступу команди на Всесоюзному конкурсі Мінсільгосп УРСР призначав наставників-тренерів. Мені та Саврану Валерію Пантелейовичу 3 Інституту тваринництва УААН (м. Харків), довелось готувати команду до Всесоюзних конкурсів в 1971, 1973, 1975, 1977, 1979, 1981, 1983, 1985, 1987 та 1989 pр. Переможцями та призерами конкурсів були майстри з Київської, Харківської, Миколаївської, Донецької, Дніпропетровської, Полтавської та інших областей.

В Україні створилась численна школа кваліфікованих майстрів машинного доїння, представниками якої стали: Шевчук Г., Гуцуляк Г., Криволап Н. 3 радгоспу «Тарасівський», Криворот К. та Засуха М. 3 дослідногогосподарства «Терезино», Григорчук Н. та Музичук Ф. 3 фермилабораторії з випробування техніки і технологій ВНДІМОТ (Дослідницьке), Єлисеєва Г. $з$ радгоспу «Шпитьківський» Київської обл., Смолякова Г. та Микитенко Н. 3 дослідного господарства ім. Фрунзе та «Кутузовка» Інституту тваринництва УААН, Скоробагатова А. 3 радгоспу ім. Червоної Армії Харківської обл., Рева В. з радгоспу «Торецький» та Федаш М. $з$ колгоспу ім. К. Маркса Донецької обл., Баштан Г., Бесараб Г., Городньова Д. та 


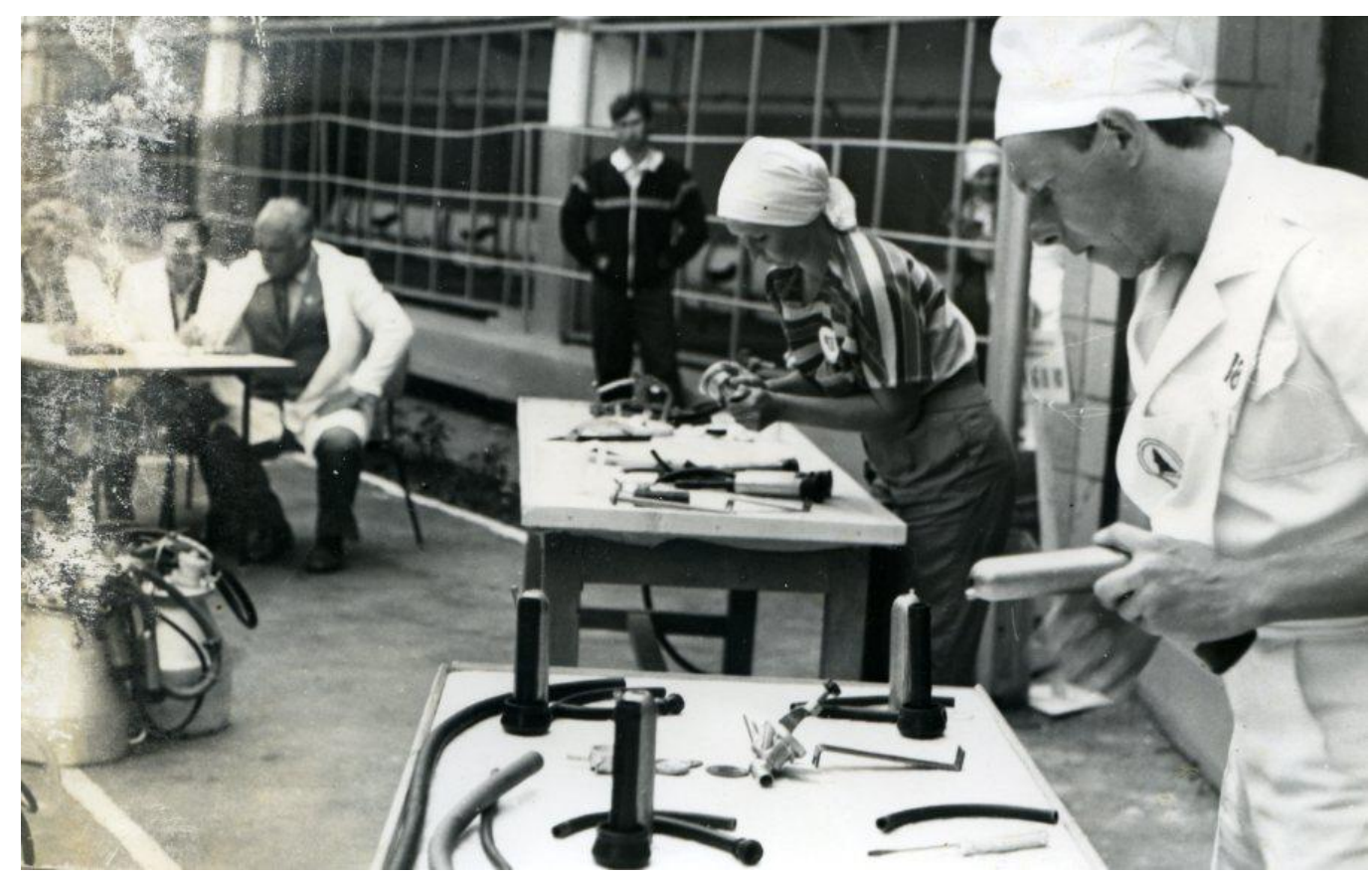

Змагаються майстри машинного доїння. Розбирання та складання доїльного апарата. Ферма «Кутузовка», Харківська обл. 1983 р.

Копилова Г. $з$ Миколаївської обл., Сотникова 3. та Комарова С. 3 Дніпропетровської обл., Шкурко П. з радгоспу Золотоніський та Москаленко Л. 3 Черкаської обл., Степанов М. 3 колгоспу «Прапор комунізму» 3 Полтавської обл., Жарков В. з радгоспу «Львівський» Херсонської обл. та багато інших. Всі вони були призерами республіканських та Всесоюзних конкурсів, нагороджені урядовими нагородами. Майстер машинного доїння Степанов Михайло Володимирович став Героєм Соціалістичної праці, кавалером двох орденів Леніна та Трудового Червоного прапора. Майстрині Засуха Марія та Скоробогатова Анжела стали Лауреатами Державної премії Союзу РСР.

Завдяки конкурсам мені пощастило побувати на фермах і комплексах 3 виробництва молока у Тульській, Вологодській та Ленінградській областях Російської Федерації, в Ташкенті та Самарканді Узбекистану, в Мінську республіки Бєларусь, м. Сігулда Латвійської РСР.

Двічі Всесоюзний конкурс проводився в дослідному господарстві «Кутузовка» НДІ тваринництва Лісостепу і Полісся України в Харківській обл. Прийоми та техніка доїння корів досвідченими майстрами нам науковцям знадобилось в подальшій науковій роботі під час вивчення біотехнічної системи «людина-машина-тварина» (ЛМТ). 
Наприкінці 60-х років Інституту було передано дослідне господарство в с. Мар'янівка Васильківського р-ну Київської обл. Це був середній за своїми показниками колгосп. Ферма 3 виробництва молока складалась 3 восьми дворядних корівників забудови кінця 50-х - початку 60 -х років 3 традиційною системою прив'язного утримання корів в стійлах і доїнням в доїльний бідон, доставкою кормів гужовим транспортом і роздачею їх вручну. Використавши наші розробки і науковий досвід, ми в одному з корівників змонтували доїльну установку типу «Молокопровід-100». Для господарства це була технологічна $\mathrm{i}$ технічна «революція».

Час вимагав сучасних технологій і рішень 3 виробництва молока на індустріальній основі, які на той час широко впроваджувались у світовій практиці. Спеціальною Постановою ЦК Компартії України та Ради Міністрів УРСР було прийнято рішення з будівництва експериментального комплексу 3 виробництва молока в с. Мар'янівка на 800 корів.

Наш відділ під керівництвом кандидата технічних наук В.А. Павленка приступив до розробки технічного завдання на будівництво такого комплексу. Розробник проекту інститут УкрНДГІПРОСІЛЬГОСП МСГ УРСР. За короткий термін проект було розроблено. Експериментальний комплекс 3 виробництва молока на 800 голів тварин складався 3 основного приміщення моноблоку блоку для утримання безприв'язно в боксах 660 дійних корів, шлейфу молодняку i родильного відділення. В кожній 310 секцій корівника розміщувалась група з 66 корів. Між двома секціями для роздачі грубих i соковитих кормів діяв стрічковий конвеєр, який завантажувався з тракторного кормороздавача кормового проїзду. Для автоматизованої подачі кормів 3 кормосховищ та кормоцеху була створена стрічкова конвеєрна лінія. Корови утримувались в боксах 3 індивідуальними перегородками та фіксуючими пристроями під час роздачі кормів. Гній накопичувався в каналах під щілинною підлогою і видалявся 3 них самопливом, а далі 3 поперечних каналів у гноєзбірник. Доїння корів виконувалось в доїльно-молочному блоці (ДМБ) на чотирьох установках УДТ-6 «Тандем». Кожні дві установки розміщувались 
паралельно в ДМБ дзеркально і мали переддоїльний майданчик в розрахунку на одну виробничу групу 66 дійних корів. Перед доїнням одну із груп направляли в переддоїльний майданчик, а потім в станки «Тандем». У літній період корів утримували на вигульних майданчиках. Кожній виробничій групі корів відповідно було обладнано майданчик з годівницями та навісами над ними. На доїння корови поступали безпосередньо з вигульних майданчиків. Молоко по молокопроводу доїльних установок транспортувалось, очищалось і охолоджувалось у потоці й направлялось в резервуари-охолоджувачі для зберігання. Експериментальна ферма була введена в експлуатацію влітку 1983 р. Вийшла на проектну потужність через три роки. На початку 90-х років експлуатацію ферми було призупинено. Основною причиною зупинення експлуатації ферми були, по-перше, зношення технологічного обладнання, подруге, занедбане ставлення до племінної роботи, в третіх - загальне зменшення поголів'я дійних корів на фермах у зв'язку з розпадом Союзу.

А взагалі, вважаємо, що на експериментальній фермі було відпрацьовано технологічний процес і комплекс машин для індустріального виробництва молока на сучасному рівні. За такими фермами - майбутнє.

Вивчаючи та узагальнюючи зарубіжні та власні дослідження, прийшли до висновку, що доїльні установки повинні складатись з окремих модулів (блоків). Для виробництва молока на фермі можна таким чином підібрати модуль на той чи інший розмір ферми. Так виник типорозмірний ряд ферм $\mathrm{P}=2^{\mathrm{n}}$, де $\mathrm{n}=1 \ldots 10$ (відповідно ферми на 2 - 1024 голів) [1, с. 240]. Важливою умовою ефективного виробництва молока є ідентичність технології і засобів доїння як взимку, так і влітку. Це спонукало науковців дослідити і розробити саме таку доїльну установку. Спільно з науковцями 3 ВІЕСГ, Казахського НДІМЕСГ, ми розробили вихідні умови та технічне завдання на таку установку. Розробник Римське ДСКБ для машин 3 тваринництва. Завод Кургансільмаш виготовив дослідну партію установок УДЛ-Ф-12 для доїння корів в літніх таборах i пасовищних центрах. Установки пройшли державні випробування i 
рекомендовані до серійного виробництва. Після розпаду Союзу ці установки випускає Брацлавський завод (ВАТ «Брацлав»).

Нові умови господарювання практично ліквідували молочні ферми 3 типовими технологічними $\mathrm{i}$ планувальними рішеннями та чисельністю поголів'я. Тепер кожний проект зі створення чи реконструкції ферми стає індивідуальним, що вимагає безлічі типорозмірів доїльних установок. У кожному замовленні, крім технологій утримання і доїння корів, визначаються окремо: чисельність поголів'я, форма і величина приміщень, рівень механізації і автоматизації процесів доїння, фінансові та кадрові можливості господарівспоживачів. Ось чому виникла потреба у створенні параметричних рядів доїльних установок для різних технологій доїння i утримання корів, планувальних рішень приміщень, чисельності поголів'я і рівня автоматизації технологічних процесів.

Основними причинами низької ефективності процесу машинного доїння корів є недоліки організаційного, технологічного і технічного характеру. До цих недоліків слід віднести: слабкий контроль параметрів процесу в зв'язку 3 його імовірнісним характером, недостатнє регулювання системи «людинамашина-тварина» (ЛМТ), які беруть участь у машинному доїнні корів, взаємна невідповідність окремих елементів і підсистем з реакції на змінні умови роботи, недосконалість основних показників (неповне видоювання корів у зв'язку 3 недостатньою підготовкою вимені, втрати найбільш жирних порцій молока, зниження якості продукції та ін.) [2, с. 292].

Отже, машинне доїння є складовою системою, в якій задіяна людина (оператор), машина (доїльний апарат і установка) та тварина (корова). Ланцюг «людина-машина-тварина(корова)» досліджувався i тепер досліджується у відділі механізації ферм великої рогатої худоби і лабораторії машинного доїння корів ННЦ «ІМЕСГ» під керівництвом лауреата Державної премії України, доктора технічних наук А.І. Фененка. Досліджували і досліджують цей ланцюг наукові співробітники: Ткач В.В., Бригас О.В., Рєзніков І.В. Вони успішно закінчили аспірантуру в ННЦ «ІМЕСГ» і захистили кандидатські дисертації. 


\section{Список використаних джерел та літератури}

1. Фененко А. И., Картанов Л. П. Режимная характеристика биотехнического звена «машина-животное» процесса выведения молока из вымени коров. Механізація та електрифікаиія сільського господарства. Глеваха, 2010. Вип. 1994. С. 240-248.

2. Москаленко С. П. Про взаємодію ланок системи «людина-машинатварина» при машинному доїнні корів. Матеріали XIX міжнародного та українського симпозіуму з питань машинного доӥння корів. Глеваха, 11-14 трав. 2004 р. Глеваха, 2005. С. 292-299.

\section{References}

1. Fenenko, A. Y., $\quad$ Kartanov, L. P. (2010). Rezhimnaja harakteristika biotehnicheskogo zvena «mashina-zhivotnoe» processa vyvedenija moloka iz vymeni korov. [The regimen characteristic of the biotechnical link «animal-animal» is the process of raising milk from the cow's mouth]. Mekhanizatsiia ta elektryfikatsiia silskoho hospodarstva [Mechanization and electrification of agriculture]. Glevaha, 1994, 240-248. [in Russian].

2. Moskalenko, S. P. (2005). Pro vzaiemodiiu lanok systemy «liudynamashyna-tvaryna» pry mashynnomu doinni koriv [Hlevakha On the interaction of parts of the system «man-machine-animal» with machine milking cows]. Materialy XIX mizhnarodnoho ta ukrainskoho sympoziumu z pytan mashynnoho doinnia koriv. [Materials of the XIX International and Ukrainian symposium on questions of machine milking of cows]. Glevaha, May 11-14, 2004. [in Ukrainian].

\section{Рецензент:}

Вергунов В.А., о.с.-г.н., акад. НААН

Надійшла до редакції 19.01.2018 р. 